\title{
Experimental Evaluation of Eco-Friendly No-Fines Geo-Polymer Concrete for Sustainable Pavement Applications
}

\author{
Mohammad Amin* and Sandeep Nasier \\ Civil Engineering Department, Chandigarh University, Chandigarh - 140413, Punjab, India; \\ aminjalili3@gmail.com, sandeep.civil@cumail.in
}

\begin{abstract}
Objectives: Water penetration and storage abilities make No-fine cement concrete unique as a pervious concrete, while using it in pavements to decrease flood risks. But still cement is the main part as a binder material, which contributes in global warming by having carbon dioxide emissions during cement production in plants. New researches have shown geo-polymer technology a good alternative material for concrete to omit cement and combat against the global warming which the world is concerned nowadays. No-fine geo-polymer concrete is the solution for both global warming and flood risks. Methods: This paper aims to find M20 grade eco-friendly no-fine geo-polymer concrete having ingredients of fly ash waste material, coarse aggregates, sodium hydroxide, sodium silicate and ground granulated blast furnace slag in different percentages to enhance its compressive strength by experimental various trials have ratio 1:4 to 1:8 of powder to aggregates. Findings: A ratio, 1:4 with 20\% replacement of fly ash by ground granulated blasted furnace slag gave satisfactory compressive strength of $21.52 \mathrm{~N} / \mathrm{mm}^{2}$ with $16632.85 \mathrm{~mm}$ /hour infiltration rate. Application/Improvements: Based on findings No-fines geo-polymer concrete can be used in low traffic pavements to combat against the flood risks and recharge ground water. Furthermore, research scholars are expected to use high morality of sodium hydroxide and lower size of aggregates which may increase the compressive strength of No-fines geo-polymer concrete.
\end{abstract}

Keywords: Flood Risks, Global Warming, Infiltration, Pervious Concrete, Sodium hydroxide, Sodium Silicate

\section{Introduction}

Urbanization is increasing along with population, needs and development of the world. Hence after water concrete becomes the most worldwide used material. Concrete having cement in large quantities as a binder material, intensively contributes in Global warming due to almost 5-7 percent of overall $\mathrm{CO}_{2}$ emissions such that producing one ton of cement has approximately one ton of carbon dioxide emissions $\frac{1-3}{}$. Hence, geo-polymer concrete zero cement concrete can be used as a potential substitute of ordinary Portland cement concrete in some fields to make the concrete ecological, green and sustainable $\underline{4-5}$ to overcome global warming caused by cement production. Geo-polymer was introduced for the first time by a French scientist Davidovits in 1972 or $1979^{6-8}$ and attracts researchers' interests nowadays for its low carbon foot print, fire resistance, acid resistance, thermal resistance and even low cost because of using waste material like fly ash as main binding material ${ }^{2}$.Geo-polymer is an inorganic construction material produced by alkaline activating aluminum-silicate material like fly ash, rice husk ash, metakaolin etc ${ }^{10}$. Geo-polymerization process is accelerated at higher temperatures compared to normal heat curing $\frac{11,12}{}$.

On other hand using no-fines geo-polymer concrete for pavements will reduce runoff water during storms by absorbing and transferring water to the ground, this will help to recharge ground ${ }^{\underline{13}}$. So using no-fines geo-polymer concrete will make pavements eco-friendly and sustainable $\frac{14}{}$. Heat Island effect and pavements noise due to vehicles will also be decreased because of low thermal and

*Author for correspondence 
sound conductivity. Another important issue in pavements is safety, Accidents take place while pavements are wet it can be avoided by no-fines pervious pavements to avoid ponds and drain water to sub base and will keep the environment green for having water saturated soil ${ }^{15}$. United States Environmental Protection Agency (EPA) has described pervious pavements as a best management practice for water management ${ }^{16}$ is can be used for sidewalks, low traffic roads, parking, and pavement in parks. Infiltration of water largely depends upon the ratio and compaction factor and aggregate size, the void ratio typically varies $15 \%$ to $30 \%$ and water to powder ratio ranges 0.2 to 0.4 . Ratios 1:8, 1:6 and 1:4 of conventional no-fines cement concrete for aggregate size $20 \mathrm{~mm}-12.5 \mathrm{~mm}$ has been practiced but recommend as a result smaller size aggregates for higher strengths for future researches in no-fines concrete ${ }^{17}$ and here this paper will work on both size of large and small aggregates for no-fines geo-polymer concrete.

\section{Materials and Methodology}

Fly ash which is rich source of silicates and aluminates for geo-polymerization was obtained from Rupor thermal power plant based in Punjab, India, having specific gravity of 2.3 as a main binding material by activating it with alkaline solution. Replacement of fly ash has been done by varying percentages of GGBS, having grey color and 2.82 specific gravity obtained from Shaktimaan cement plant based in Yamuna Nagar. Alkalinesolution is a mixture of sodium hydroxide and sodium silicate. Sodium Hydroxide flakes were purchased from local suppliers and then 12 moles of solution were prepared. As its molecular weight is 40 grams to make 1 Liter solution having 12 moles morality, 480 grams of sodium hydroxide flakes were dissolved in certain amount of water to gain 1 liter of sodium hydroxide solution of 12 moles. Sodium silicate is available in solution for having concentration 40-54 $\%$. A solution with $52 \%$ concentration was used for this experimental work. The 1:2.5 ratio of sodium hydroxide to sodium silicate were adopted for all mixes. The amount of extra water found by subtracting of water present in alkaline solution from overall amount of water calculated by $0.4,0.38$ and 0.36 water to powder ratios. Aggregates size passing through $20 \mathrm{~mm}$ sieve andretaining on 12.5 $\mathrm{mm}$ sieve and $10 \mathrm{~mm}$ passing retained on $8 \mathrm{~mm}$ were used with specific gravity of 2.63 to achieve high strength and good appearance of the surface.

\subsection{Mixing}

Mixing design for no-fines geo-polymer concrete has been done according to (IS: 12727:1999)after batching of materials, coarse aggregates were wet with water then fly ash and GGBS were mixed with aggregates to cover its surface, then prepared solution and remaining extra water were added into mix and continued mixing for 10 minutes by hand mixing. Overall 15 Mixes of 90 cubes were casted for compressive strength test. 9 mixes for $20 \mathrm{~mm}-12.5 \mathrm{~mm}$ aggregates and 6 trails for $10 \mathrm{~mm}-8 \mathrm{~mm}$ sieves with various percentages of GGBS and water to powder ratio as shown in (Table 1).

\subsection{Curing}

Curing procedure differ from conventional concrete such that geo-polymer concrete does not need water curing. To gain strength geo-polymer concrete needs heat. Socuring is done in oven for 24 hours of 90 -degree Celsius heat after opening the molds of $150 \times 150 \times 150 \mathrm{~mm}^{3}$. While after completion 24 hours of curing specimens were kept in room temperature for 7 days and 28 days of curing.

\section{Test Results and Discussions}

\subsection{Compressive Strength}

Specimens were tested in universal compression testing machine as per (IS 516:1959-2004) $\frac{18}{2}$ to the find out their compressive strength after 7 and 28 days of curing as per (Table 2). There are various factors affecting compressive strength of the concrete. Increase in amount of ground granulated blast furnace slag increases the strength in each ratio considering also the compaction factor. The strength also gradually increased by increasing the ratio from 1:8 to $1: 4$ for the mixes. There is a decrease in strength of concrete by increasing the amount of GGBS for ratio $1: 8$, this is because of reduction in amount of fly ash which the main binding material having silicates and aluminates in its composition and activated by alkaline solution and act as a cement in geo-polymer concrete and lowering the size of aggregate shows satisfactory increase of compressive strength such that reached $21.5 \mathrm{~N} / \mathrm{mm}^{2}$ compressive strength by just $20 \%$ replacement of fly ash by GGBS comparing to large size aggregate at same ratio with $30 \%$ GGBS having just $15.1 \mathrm{~N} / \mathrm{mm}^{2}$ of compressive strength. 
Table 1. Materials proportions for 1 cubic meter of concrete

\begin{tabular}{|c|c|c|c|c|c|c|c|c|c|c|}
\hline \multirow{2}{*}{ Mix ID } & \multirow{2}{*}{ Ratio } & \multicolumn{2}{|c|}{ Binder (\%) } & \multicolumn{6}{|c|}{ Quantities (kg/m3) } & \multirow{2}{*}{$\begin{array}{l}\text { water/ } \\
\text { Powder }\end{array}$} \\
\hline & & Fly ash & GGBS & fly ash & GGBS & C.Agg & $\mathrm{NaOH}$ & $\mathrm{Na} 2 \mathrm{SiO} 3$ & Water & \\
\hline \multicolumn{11}{|c|}{ Aggregate size $20-12.5 \mathrm{~mm}$} \\
\hline Mix 1 & $1: 8$ & 100 & 0 & 306.667 & 0 & 2137.778 & 35.048 & 87.619 & 61.333 & 0.4 \\
\hline $\operatorname{Mix} 2$ & $1: 6$ & 100 & 0 & 361.429 & 0 & 2063.905 & 41.306 & 103.265 & 62.166 & 0.38 \\
\hline Mix 3 & $1: 4$ & 100 & 0 & 506 & 0 & 1924 & 57.829 & 144.571 & 76.912 & 0.36 \\
\hline Mix 4 & \multirow{2}{*}{$1: 8$} & 80 & 20 & 245.33 & 61.33 & 2137.78 & 35.05 & 87.62 & 61.33 & 0.4 \\
\hline Mix 5 & & 70 & 30 & 214.67 & 92.00 & 2137.78 & 35.05 & 87.62 & 61.33 & 0.4 \\
\hline Mix 6 & \multirow{2}{*}{$1: 6$} & 80 & 20 & 289.14 & 72.29 & 2063.91 & 41.31 & 103.27 & 62.17 & 0.38 \\
\hline Mix 7 & & 70 & 30 & 253.00 & 108.43 & 2063.91 & 41.31 & 103.27 & 62.17 & 0.38 \\
\hline Mix 8 & \multirow{2}{*}{$1: 4$} & 80 & 20 & 404.80 & 101.20 & 1924.00 & 57.83 & 144.57 & 76.91 & 0.36 \\
\hline Mix 9 & & 70 & 30 & 354.20 & 151.80 & 1924.00 & 57.83 & 144.57 & 76.91 & 0.36 \\
\hline \multicolumn{11}{|c|}{ Aggregate size $10-8 \mathrm{~mm}$} \\
\hline Mix 10 & \multirow{2}{*}{$1: 8$} & 90 & 10 & 276.00 & 30.67 & 2137.78 & 35.05 & 87.62 & 61.33 & 0.4 \\
\hline Mix 11 & & 80 & 20 & 224.89 & 61.33 & 2137.78 & 35.05 & 87.62 & 61.33 & 0.4 \\
\hline Mix 12 & \multirow{2}{*}{$1: 6$} & 90 & 10 & 325.29 & 36.14 & 2063.90 & 41.31 & 103.27 & 62.17 & 0.38 \\
\hline Mix 13 & & 80 & 20 & 289.14 & 72.29 & 2063.90 & 41.31 & 103.27 & 62.17 & 0.38 \\
\hline
\end{tabular}

Table 2. Compressive strength of concrete at different ages of curing

\begin{tabular}{|c|c|c|c|c|c|c|c|}
\hline \multirow{2}{*}{ Mix ID } & \multirow{2}{*}{ Ratio } & \multicolumn{2}{|c|}{ Binder (\%) } & \multicolumn{2}{|c|}{ Compressive Strength (N/mm2) } & \multirow{2}{*}{$\begin{array}{l}\text { Density } \\
(\mathrm{kg} / \mathrm{mm} 3)\end{array}$} & \multirow{2}{*}{$\begin{array}{l}\text { Compaction } \\
\text { Factor }\end{array}$} \\
\hline & & Fly ash & GGBS & 7 days & 28days & & \\
\hline \multicolumn{8}{|c|}{ Aggregate size $20-12.5 \mathrm{~mm}$} \\
\hline Mix 1 & $1: 8$ & 100 & 0 & 4.50 & 4.50 & 1894.00 & 0.875 \\
\hline Mix 2 & $1: 6$ & 100 & 0 & 5.30 & 9.80 & 1888.00 & 0.879 \\
\hline Mix 3 & $1: 4$ & 100 & 0 & 6.40 & 10.40 & 1876.00 & 0.88 \\
\hline Mix 4 & \multirow{2}{*}{$1: 8$} & 80 & 20 & 3.50 & 6.12 & 1922.00 & 0.856 \\
\hline Mix 5 & & 70 & 30 & 2.20 & 5.00 & 1928.00 & 0.844 \\
\hline Mix 6 & \multirow{2}{*}{$1: 6$} & 80 & 20 & 4.20 & 10.20 & 1896.00 & 0.85 \\
\hline Mix 7 & & 70 & 30 & 7.10 & 11.30 & 1911.00 & 0.84 \\
\hline Mix 8 & \multirow{2}{*}{$1: 4$} & 80 & 20 & 7.30 & 12.40 & 1890.00 & 0.877 \\
\hline Mix 9 & & 70 & 30 & 10.30 & 15.10 & 1899.00 & 0.866 \\
\hline \multicolumn{8}{|c|}{ Aggregate size $10-8 \mathrm{~mm}$} \\
\hline Mix 10 & \multirow{2}{*}{$1: 8$} & 90 & 10 & 8.40 & 10.20 & 2014.00 & 0.84 \\
\hline Mix 11 & & 80 & 20 & 4.20 & 9.40 & 2020.00 & 0.838 \\
\hline Mix 12 & \multirow{2}{*}{$1: 6$} & 90 & 10 & 7.10 & 11.60 & 1982.00 & 0.823 \\
\hline Mix 13 & & 80 & 20 & 10.40 & 13.90 & 1991.00 & 0.819 \\
\hline Mix 14 & \multirow{2}{*}{$1: 4$} & 90 & 10 & 13.80 & 17.00 & 1976.00 & 0.82 \\
\hline Mix 15 & & 80 & 20 & 14.50 & 21.50 & 1994.00 & 0.81 \\
\hline
\end{tabular}




\subsection{Infiltration Rate}

Infiltration rate is a vital factor for pervious concrete to show the ability of filtering an amount of water within a specific duration of time. Which can help to describe range of risk reduction of floods in rainy areas and will help in recharge of ground water by absorbing and delivering the water to the ground under the geo-polymer concrete? Infiltration rate was tested and recorded according to (ASTM C1701) $\frac{19}{19}$ shown in (Table 3) which determines amount of filtered water within a specific time. The tests show high filtration of water show in samples and ring for infiltration. The infiltration test ring and procedure are shown in (Figure 1-3).

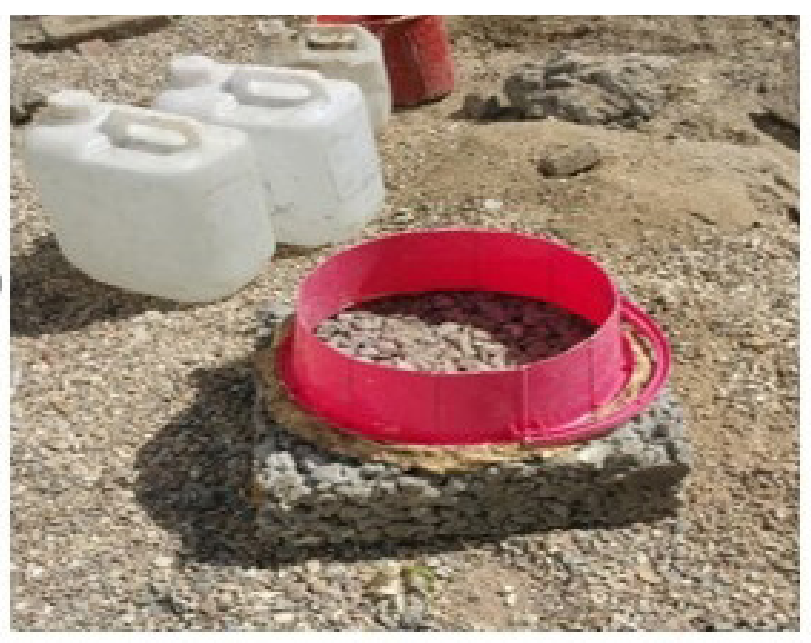

Figure 2. Sample and ring for infiltration test.

Table 3. Input required data for calculating concrete infiltration

\begin{tabular}{|c|c|c|c|c|c|c|}
\hline Ratio & Water/Powder & M (kg) & $\mathrm{D}(\mathbf{m m})$ & $\mathrm{T}(\mathrm{sec})$ & $\mathbf{K}$ & I $(\mathbf{m m} / \mathbf{h r})$ \\
\hline \multicolumn{7}{|c|}{ Aggregate size 20-12.5 mm } \\
\hline $1: 8$ & 0.4 & 18 & 295 & 36 & 4583666000 & 26335.34 \\
\hline $1: 6$ & 0.38 & 18 & 295 & 44 & 4583666000 & 21547.1 \\
\hline $1: 4$ & 0.36 & 18 & 295 & 48 & 4583666000 & 19751.51 \\
\hline \multicolumn{7}{|c|}{ Aggregate size $10-8 \mathrm{~mm}$} \\
\hline $1: 8$ & 0.4 & 18 & 295 & 43 & 4583666000 & 22048.19 \\
\hline $1: 6$ & 0.38 & 18 & 295 & 51 & 4583666000 & 18589.65 \\
\hline $1: 4$ & 0.36 & 18 & 295 & 57 & 4583666000 & 16632.85 \\
\hline
\end{tabular}

Figure 1 Infiltration Rate for various size of aggregates in different Mix ratios

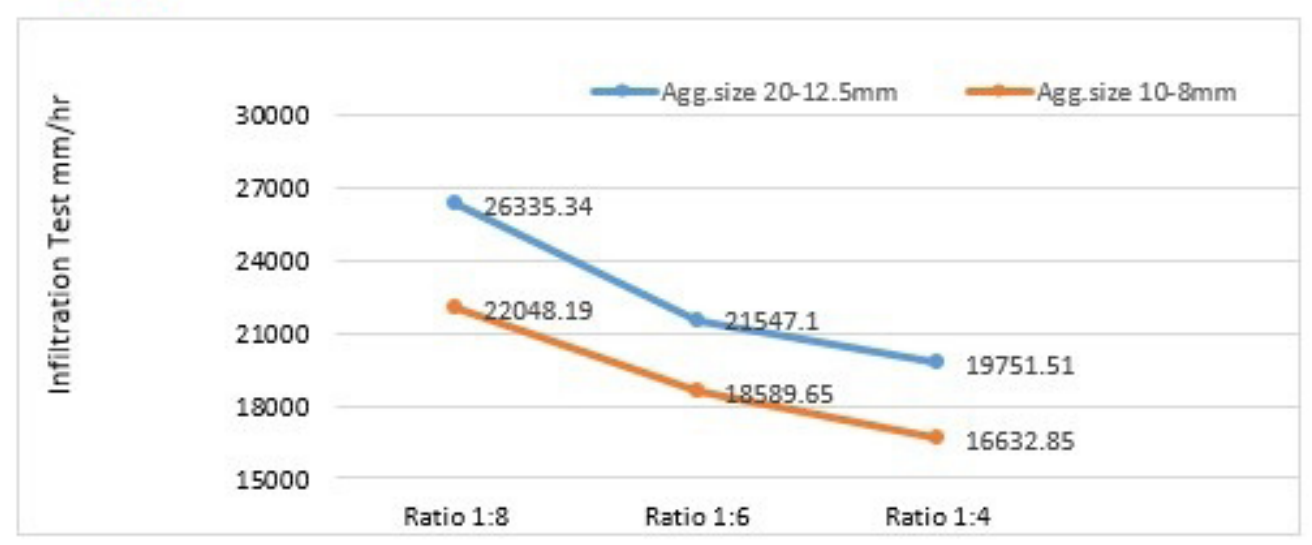

Figure 1. Infiltration rate for various sizes of aggregates in different mix ration. 


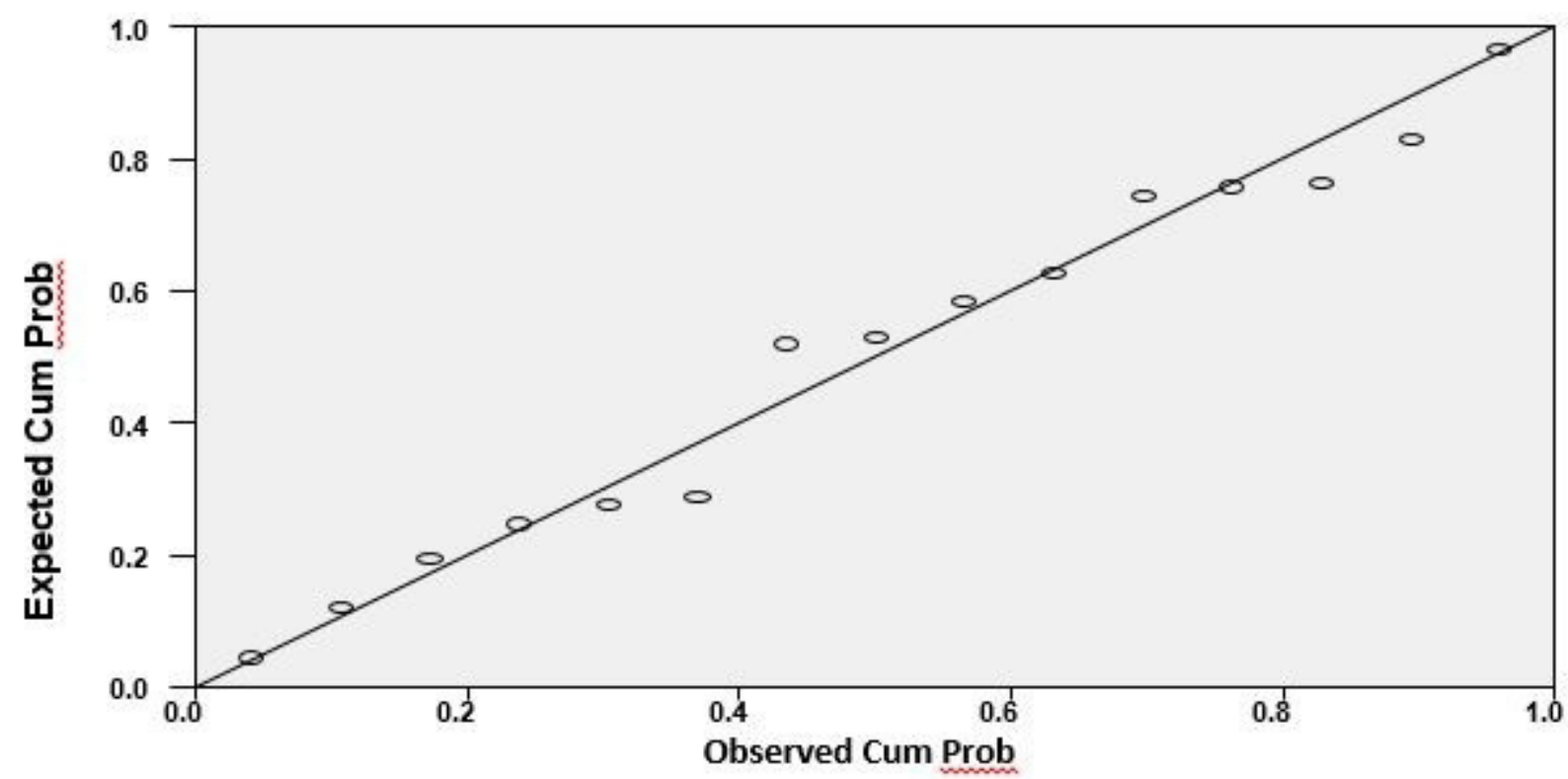

Figure 3. Normal P-Plot of regression standardized residual.

\section{Procedure:}

1. A ring of $300 \mathrm{~mm}$ diameter with $50 \mathrm{~mm}$ height was taken and putted on concrete slab.

2. $2 \mathrm{~kg}$ of water is used for pre-watering and after 30 seconds $18 \mathrm{~kg}$ of water is allowed to pass the concrete slab and time is recorded within the head between $10 \mathrm{~mm}$ to $15 \mathrm{~mm}$ of water inside the circle.

3. Equation (1) for infiltration calculation

$I=\frac{K * M}{D^{2} * T}$

Equation (1)

$\mathrm{I}=$ infiltration Rate $(\mathrm{mm} / \mathrm{hr})$

$\mathrm{D}=$ Diameter $(\mathrm{mm})$

$\mathrm{T}=$ Time $(\mathrm{Sec})$

$\mathrm{K}=$ constant

$\mathrm{M}=$ mass of water $(\mathrm{kg})$

\subsection{Porosity Test}

Porosity shows the amount of voids present in a sample which highly affect the compressive strength of concrete. Porosity has been decreased by using smaller aggregates and compact the concrete. Pores exist generally in three types unintentionally in concrete. Capillary pores exist between paste and aggregates and owns most part of the voids, Gel pores exists with the gel and intra-crystal pores exists in crystals.

\subsubsection{Porosity by Weight}

Porosity test has been performed for three ratios for both sizes of aggregates according to (ASTM C1754)by weight as per Table 4, Equation (2)

$\mathrm{Vr}=100^{*}[1-\{(\mathrm{W} 2-\mathrm{W} 1) /(\mathrm{Pw}-\mathrm{V})\}] \ldots \quad$ Equation $(2)$

$\mathrm{W} 2=$ Oven dried weight

$\mathrm{W} 1=$ Weight under water for 24 hours

$\mathrm{Pw}=$ density of water

$\mathrm{V}=$ volume of specimen

$\mathrm{Vr}=$ Porosity

\subsubsection{Porosity by Volume}

Sample is putted in a pre-measured amount of water and record the increased level amount of water as second volume. By simple equations porosity can be found as per Table 5, Equation (3): 
Table 4. Porosity calculation parameters by weight

\begin{tabular}{|c|c|c|c|c|c|}
\hline Ratio & W1 (kg) & W2 (kg) & $\mathrm{pw}\left(\mathrm{kg} / \mathrm{m}^{3}\right)$ & $\mathbf{V}\left(\mathbf{m}^{3}\right)$ & $\mathbf{P}(\%)$ \\
\hline \multicolumn{6}{|c|}{ Aggregate size $20-12.5 \mathrm{~mm}$} \\
\hline $1: 8$ & 5.7 & 6.4 & 1000 & 0.003 & 20.5 \\
\hline $1: 6$ & 5.52 & 6.4 & 1000 & 0.003 & 25.2 \\
\hline $1: 4$ & 5.31 & 6.3 & 1000 & 0.003 & 30.3 \\
\hline \multicolumn{6}{|c|}{ Aggregate size $10-8 \mathrm{~mm}$} \\
\hline $1: 8$ & 6.4 & 6.8 & 1000 & 0.003 & 11.9 \\
\hline $1: 6$ & 6.12 & 6.6 & 1000 & 0.003 & 16.9 \\
\hline $1: 4$ & 5.89 & 6.67 & 1000 & 0.003 & 23.1 \\
\hline
\end{tabular}

$\mathrm{P}=[\{\mathrm{V} 1-(\mathrm{V} 3-\mathrm{V} 2)\} / \mathrm{V} 1]{ }^{\star} 100 \ldots . .$. Equation $(3)$

V1= sample volume

$\mathrm{V} 2=$ water volume

$\mathrm{V} 3=($ Water + sample $)$ volume

V3-V2= Particles Volume

$\{\mathrm{V} 1-(\mathrm{V} 3-\mathrm{V} 2)\}=$ pores volume

$\mathrm{P}=$ Porosity in Percent

\section{Statistical Analysis}

\subsection{Correlation}

Correlation statistical analysis has been performed to find relations between the variables (Figure 4). First we should justify dependent and independent variables. Independent variables are the inputs such as Ratio, Aggregate size, Fly ash, C.A and alkaline solutions and dependent variables are the outputs like compressive strength, infiltration rate, porosity, and density. Correlation coefficient describes how much one variable has relation or can be changed by changes in other variable. The correlation ranges between -1 to +1 . Values near to +1 shows high positive relations of the variables and coefficients near to -1 show high negative correlations between the variables. For this research compressive strength has high positive correlations with ratio, sodium hydroxide and sodium silicate where increase in these correlations coefficients will result increase in compressive strength (Table 6). But aggregate size, amount to coarse aggregates and water/ ratio have negative correlation with compressive strength which actually by increase in these parameters the compressive strength with have reduction. So we can decide a sufficient amount of each parameter to reach a target compressive strength. Similarly changing ratio from 1:8 to $1: 4$, increase in fly ash, ggbs and alkaline solution, infiltration rate will decrease due to negative correlation and will increase infiltration rate by increasing aggregate size and water/powder ratio.

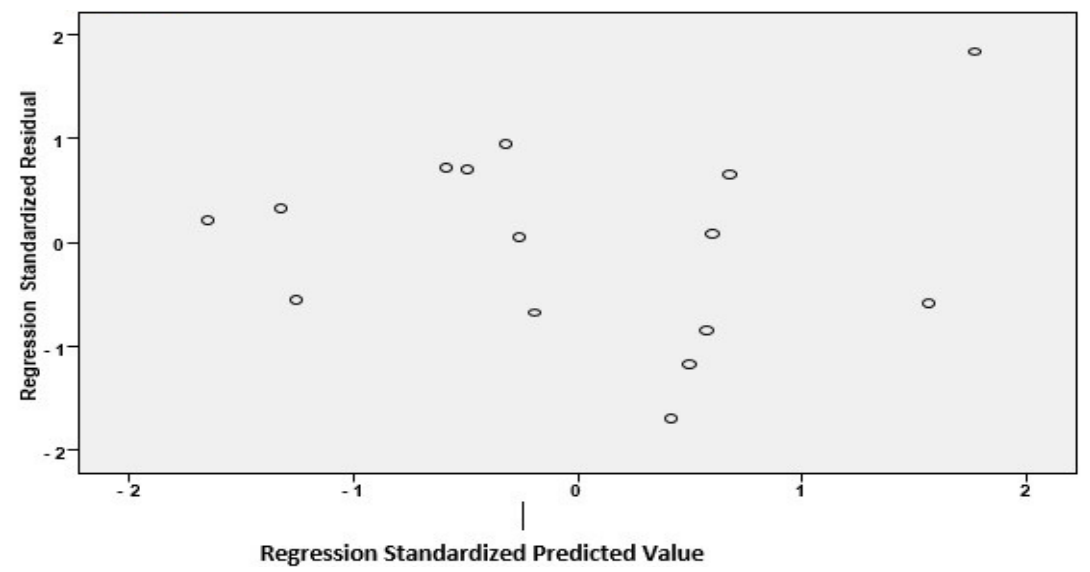

Figure 4. Scatter plot for relation between dependent and independent variables. 
Table 5. Porosity calculation parameters by volume

\begin{tabular}{|c|c|c|c|c|c|c|}
\hline \multirow{2}{*}{ Ratio } & \multicolumn{5}{|c|}{ Volume (m3) } & \multirow{2}{*}{ P (\%) } \\
\cline { 2 - 6 } & V1 & V2 & V3 & V3-V2 & $\{$ V1-(V3-V2) & \\
\hline \multicolumn{2}{|c|}{ Aggregate size 20-12.5 $\mathbf{~ m m ~}$} & & & & & \\
\hline $1: 8$ & 0.003 & 0.028 & 0.03 & 0.003 & 0.001 & 21.748 \\
\hline $1: 6$ & 0.003 & 0.029 & 0.031 & 0.002 & 0.001 & 32.927 \\
\hline $1: 4$ & 0.003 & 0.028 & 0.031 & 0.002 & & \\
\hline \multicolumn{2}{|l|}{ Aggregate size 10-8 $\mathbf{~ m m}$} & & & & 11.1111 \\
\hline $1: 8$ & 0.0034 & 0.028 & 0.031 & 0.003 & 0.0004 & 18.5538 \\
\hline $1: 6$ & 0.0034 & 0.028 & 0.0307 & 0.0027 & 0.0006 & 24.1432 \\
\hline $1: 4$ & 0.0034 & 0.028 & 0.0306 & 0.0026 & 0.0008 & \\
\hline
\end{tabular}

Table 6. Correlation between dependent and independent variable

\begin{tabular}{|l|l|l|l|l|l|l|l|l|l|l|l|l|l|}
\hline & Ratio & $\begin{array}{l}\text { Agg } \\
\text { Size }\end{array}$ & fly ash & GGBS & CA & NaOH & Na2si3 & $\begin{array}{l}\text { water/ } \\
\text { Powder }\end{array}$ & C.F & $\begin{array}{l}\text { Density } \\
\text { kg/mm3 }\end{array}$ & $\begin{array}{l}\text { I mm/ } \\
\text { hr }\end{array}$ & P (\%) $)$ & $\begin{array}{l}\text { com- } \\
\text { pressive } \\
\text { strength }\end{array}$ \\
\hline Ratio & 1.000 & & & & & & & & & & & & \\
\hline Agg.size & 0.000 & 1.000 & & & & & & & & & & & \\
\hline fly ash & 0.866 & -0.018 & 1.000 & & & & & & & & & & \\
\hline GGBS & 0.312 & 0.074 & -0.200 & 1.000 & & & & & & & & & \\
\hline CA & -1.000 & 0.000 & -0.865 & -0.312 & 1.000 & & & & & & & & \\
\hline NaOH & 0.998 & 0.000 & 0.866 & 0.313 & -0.997 & 1.000 & & & & & & & \\
\hline Na2si3 & 0.998 & 0.000 & 0.866 & 0.313 & -0.997 & 1.000 & 1.000 & & & & & & \\
\hline $\begin{array}{l}\text { water/ } \\
\text { Powder }\end{array}$ & -0.982 & 0.000 & -0.842 & -0.303 & 0.984 & -0.968 & -0.968 & 1.000 & & & & & \\
\hline C.F & 0.034 & 0.813 & 0.186 & -0.258 & -0.031 & 0.044 & 0.044 & -0.001 & 1.000 & & & & \\
\hline Density & -0.220 & -0.946 & -0.258 & 0.032 & 0.222 & -0.212 & -0.212 & 0.239 & -0.823 & 1.000 & & & \\
\hline I (mm/hr) & -0.761 & 0.549 & -0.652 & -0.191 & 0.765 & -0.738 & -0.738 & 0.810 & 0.453 & -0.316 & 1.000 & & \\
\hline P (\%) & 0.707 & 0.686 & 0.595 & 0.268 & -0.709 & 0.695 & 0.695 & -0.725 & 0.536 & -0.827 & -0.209 & 1.000 & \\
\hline $\begin{array}{l}\text { Com. } \\
\text { Strength }\end{array}$ & 0.761 & -0.510 & 0.551 & 0.411 & -0.763 & 0.748 & 0.748 & -0.778 & -0.522 & 0.344 & -0.916 & 0.215 & 1.000 \\
\hline
\end{tabular}

\subsection{Stepwise Multiple Linear Regression}

While correlation between the variables has been found coming to the next step to find out the most engaged variables which contributes in enhancing the compressive strength in our model from which then we can predict the coefficients of the variables as per regression formula to predict the changes we need for future researches or changes. In multiple stepwise linear regression, the most important variable is find out by regression then again this variable may affect much more by including another variable to find combination of variables that jointly contributes or our dependent variable is relying on those variables. This stepwise linear regression has been performed in SSPS application. Prior to regression analysis descriptive analysis is done to find out the mean and standard deviation Table 7. For compressive strength two models have been made for compressive strength as shown in Table 8 water/powder ratio and then including two that density makes second model. Model summery Table 9 shows that water to powder ratio defines the model by $60 \%$ including density in second model modifies the model by $90 \%$ and Table 10 shows significance of model which less than 0.05 or $5 \%$ continuing with accuracy of the statistical data in Table 11 which really near to 
the base line showing accurate regression. So writing the formula for stepwise linear regression is:

$\mathrm{Y}=\mathrm{b}_{0}+\mathrm{b}_{1} \mathrm{X}_{1}+\mathrm{b}_{2} \mathrm{X}_{2}+\mathrm{b}_{3} \mathrm{X}_{3}+\mathrm{b}_{4} \mathrm{X}_{4} \cdots$

$\mathrm{Y}=7.994-0.913 \mathrm{X}_{1}+0.562 \mathrm{X}_{2} \cdots$

able 7. Descriptive statistics (mean and standard deviation)

\begin{tabular}{|l|l|l|l|}
\hline & Mean & Std.Deviation & N \\
\hline Compressive Strength & 11.2426 & 4.463 & 15 \\
Fly ash & 327.383 & 86.036 & 15 \\
GGBS & 62.618 & 44.49 & 15 \\
$\mathrm{CA}$ & 2041.894 & 91.762 & 15 \\
$\mathrm{NaOH}$ & 44727 & 9.947 & 15 \\
$\mathrm{Na} 2 \mathrm{Si3}$ & 111.818 & 24.867 & 15 \\
\hline Compaction factor & 0.84777 & 0.023 & 15 \\
Density & 1939.12 & 51.311 & 15 \\
Ratio & 0.18 & 0.537 & 15 \\
Agg.size & 13.35 & 3.676 & 15 \\
Water/Powder & 0.38 & 0.016 & 15 \\
\hline
\end{tabular}

Table 8. Important models based on probability criteria (significant of parameters in mix)

\begin{tabular}{|l|l|l|l|}
\hline Model & Variables Entered & Variables Removed & Method \\
\hline 1 & & & $\begin{array}{l}\text { Stepwise } \\
\text { Criteria: } \\
\text { Probability of F to Enter }<=050 . \\
\text { Probability of F Remove }>=100) .\end{array}$ \\
\hline 2 & Water/Powder & & $\begin{array}{l}\text { Stepwise } \\
\text { Criteria: } \\
\text { Probability of F to Enter }<=050 . \\
\text { Probability of F Remove }>=100) .\end{array}$ \\
\hline
\end{tabular}

Table 9. R square table showing the level significant of the models (Water/Powder, Density)

\begin{tabular}{|c|c|c|c|c|c|c|c|c|c|}
\hline \multirow[b]{2}{*}{ Model } & \multirow[b]{2}{*}{$\mathrm{R}$} & \multirow[b]{2}{*}{ R Square } & \multirow[b]{2}{*}{$\begin{array}{l}\text { Adjusted R } \\
\text { Square }\end{array}$} & \multirow{2}{*}{$\begin{array}{l}\text { Std. Error } \\
\text { of the } \\
\text { Estimate }\end{array}$} & & \multicolumn{3}{|c|}{ Change Statistics } & \multirow[b]{2}{*}{$\begin{array}{l}\text { Sig. F } \\
\text { Change }\end{array}$} \\
\hline & & & & & $\begin{array}{l}\text { R Square } \\
\text { Change }\end{array}$ & $\begin{array}{l}\text { F } \\
\text { Change }\end{array}$ & df1 & df2 & \\
\hline $\begin{array}{l}1 \\
2\end{array}$ & $\begin{array}{l}.778 \mathrm{a} \\
.951 \mathrm{~b}\end{array}$ & $\begin{array}{l}.606 \\
.904\end{array}$ & $\begin{array}{l}.575 \\
.888\end{array}$ & $\begin{array}{l}2.908141 \\
1.495401\end{array}$ & $\begin{array}{l}.606 \\
.298\end{array}$ & $\begin{array}{l}19.973 \\
37.165\end{array}$ & $\begin{array}{l}1 \\
1\end{array}$ & $\begin{array}{l}13 \\
12\end{array}$ & $\begin{array}{l}.001 \\
.000\end{array}$ \\
\hline
\end{tabular}

Table 10. Significant of regression (affective of based independent parameters to dependent parameters)

\begin{tabular}{|l|r|r|r|r|l|}
\hline Model & Sum of squares & $\mathrm{df}$ & Mean Square & \multicolumn{1}{|c|}{ S } & Sig. \\
\hline \multirow{2}{*}{ 1. Regression Residual } & 168.921 & 1 & 168.921 & 19.973 & $.001^{\mathrm{b}}$ \\
Total & 109.945 & 13 & 8.457 & & \\
\hline \multirow{2}{*}{ 2. Regression Residual } & 278.866 & 14 & & & \\
Total & 252.031 & 2 & 126.016 & 56.352 & $.000^{\mathrm{c}}$ \\
& 26.835 & 12 & 2.236 & & \\
\hline
\end{tabular}


Table 11. Residuals statistics of the models showing accuracy of the model

\begin{tabular}{|l|l|l|l|l|l|}
\hline & Minimum & Maximum & Mean & Std.Deviation & $\mathrm{N}$ \\
\hline Predicted Value & 4.226 & 18.749 & 11.242 & 4.242 & 15 \\
Residual & -2.527 & 2.75 & 0.000 & 1.384 & 15 \\
Std.Predicted value & -1.654 & 1.769 & 0.000 & 1.000 & 15 \\
Std. Residual & -1.697 & 1.839 & 0.000 & 0.926 & 15 \\
\hline
\end{tabular}

Table 12. Co-efficient to predict the dependent variable based on regression formula

\begin{tabular}{|c|c|c|c|c|c|c|c|c|}
\hline \multirow[b]{2}{*}{ Model } & & \multicolumn{2}{|c|}{ Unstandardized Coefficients } & \multirow{2}{*}{$\begin{array}{l}\text { Standardized } \\
\text { Coefficients } \\
\text { Beta }\end{array}$} & \multirow[b]{2}{*}{$\mathrm{t}$} & \multirow[b]{2}{*}{ Sig. } & \multicolumn{2}{|c|}{ Collinearity Statistics } \\
\hline & & B & Std. Error & & & & Tolerance & VIF \\
\hline 1 & $\begin{array}{l}\text { (Constant) } \\
\text { water/ Powder }\end{array}$ & $\begin{array}{l}89.333 \\
-205.500\end{array}$ & $\begin{array}{l}17.489 \\
45.982\end{array}$ & -.778 & $\begin{array}{l}5.108 \\
-4.469\end{array}$ & $\begin{array}{l}.000 \\
.001\end{array}$ & 1.000 & 1.000 \\
\hline 2 & $\begin{array}{l}\text { (Constant) } \\
\text { water/ Powder } \\
\text { Density } \\
(\mathrm{kg} / \mathrm{mm} 3)\end{array}$ & $\begin{array}{l}7.994 \\
-240.998 \\
.049\end{array}$ & $\begin{array}{l}16.090 \\
24.351 \\
.008\end{array}$ & -.913 .562 & $\begin{array}{l}.497 \\
-9.897 \\
6.096\end{array}$ & $\begin{array}{l}.628 \\
.000 \\
.000\end{array}$ & $\begin{array}{l}.943 \\
.943\end{array}$ & $\begin{array}{l}1.061 \\
1.061\end{array}$ \\
\hline
\end{tabular}

\section{Conclusion}

From environmental and storm water management aspect enhancing the technology of No-fines geo-polymer technology will result good for global warming reduction and minimizing flood risks because of no cement present in geo-polymer concrete and the ability of absorbing large amount of water. Enough strength and infiltration rate is achieved which can be used for low traffic roads and pavements. Future studies are expected from researchers in this field with lower size aggregates, temperatures and high morality of sodium hydroxide to make environment green and sustainable.

\section{References}

1. Shaikh FUA. Mechanical and durability properties of fly ash geo-polymer concrete containing recycled coarse aggregates. International Journal of Sustainable Built Environment. 2016; 5(2):277-87. Crossref.

2. Petrillo A, Cioffi C. Eco-sustainable geo-polymer concrete blocks production process. Agriculture and Agricultural Science Procedia. 2016; 8:408-18. Crossref.

3. Banupriya C, John S, Suresh R, Divya E, Vinitha D. Experimental Investigations ongeo-polymer Bricks/Paver Blocks. Indian Journal of Science and Technology. 2016; 9(16):1-5. Crossref.
4. Deb PS, Nath P, Sarker PK. Drying shrinkage of slag blended fly ash geo-polymer concrete cured at room temperature. Procedia Engineering. 2015; 125:594-600. Crossref.

5. Blaszcynski T, Krol M. Usage of green concrete technology in civil engineering. Procedia Engineering. 2015; 122:296301. Crossref.

6. Rashida $\mathrm{MH}$, Zakria M, Khairun AA. Concentration of $\mathrm{NaOH}$ and the effect on the properties of fly ash based geo-polymer. Procedia Engineering. 2016; 148:189-93. Crossref.

7. Adam AA, Horianto X. The effect of temperature and duration of curing on the strength of fly ash based geo-polymer mortar. Procedia Engineering. 2014; 95:410-4. Crossref.

8. Abdul Aleem MI, Arumairaj PD. Optimum mix for the geo-polymer concrete. Indian Journal of Science and Technology. 2012; 5(3):1-3.

9. Zhuang HJ, Zhang HY. Resistance of geopolymer mortar to acid and chloride attacks. Procedia Engineering. 2017, 210, pp. 126-131. Crossref.

10. Joseph B, Mathew G. Influence of aggregate content on the behavior of fly ash based geo-polymer concrete. Scientia Iranica A. 2012; 19(5):1188-94. Crossref.

11. Nath P, Sarker PK. Early age properties of low-calcium fly ash geo-polymer concrete suitable for ambient curing. Procedia Engineering. 2015; 125:601-7. Crossref.

12. Mahendran K, Arunachelam N. Performance of fly ash and copper slag based geo-polymer concrete. Indian Journal of Science and Technology. 2016; 9(2):1-6. Crossref.

13. Alam A, Naz S. Experimental study on properties of nofine concrete. International Journal of Informative and Futuristic Research. 2015; 3687-94. 
14. Rangelov M, NassiriS. Quality evaluation tests for pervious concrete pavements' placement. International Journal of Pavement Research and Technology. 2017; 10:245-53. Crossref.

15. Bonicelli A, Arguelles GM. Improving pervious concrete pavements for achieving more sustainable Urban Roads. Procedia Engineering. 2016; 161: 1568-73. Crossref.

16. Maguesvari MU, Narasimha VL. Studies on characterization of pervious concrete for pavement applications.
Procedia - Social and Behavioral Sciences. 2013; 104:198207. Crossref.

17. Mageswari M, Karthikeyan MP. High strength permeable pavement using no fines concrete. SSRG International Journal of Civil Engineering. 2016; 3(3):62-6. Crossref.

18. Bureau of Indian Standards. Available from: https:// en.wikipedia.org/wiki/Bureau_of_Indian_Standards

19. ASTM International. Available from: https://en.wikipedia. org/wiki/ASTM_International 